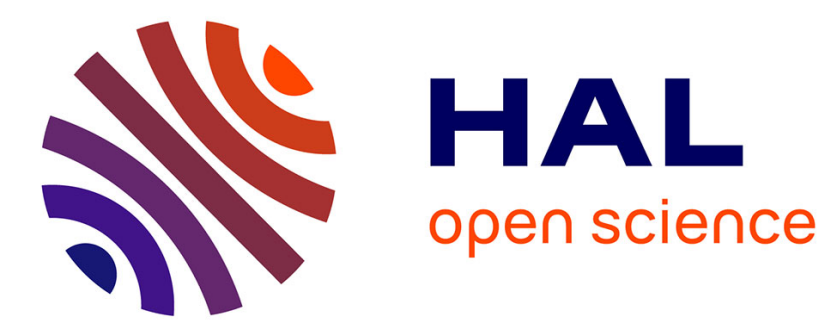

\title{
Two new long-legged flies in the Santonian amber of France (Diptera: Dolichopodidae)
}

\author{
André Nel, Romain Garrouste, Christophe Daugeron
}

\section{To cite this version:}

André Nel, Romain Garrouste, Christophe Daugeron. Two new long-legged flies in the Santonian amber of France (Diptera: Dolichopodidae). Cretaceous Research, 2017, 69, pp.1-5. 10.1016/j.cretres.2016.08.009 . hal-01369622

\section{HAL Id: hal-01369622 https://hal.sorbonne-universite.fr/hal-01369622}

Submitted on 21 Sep 2016

HAL is a multi-disciplinary open access archive for the deposit and dissemination of scientific research documents, whether they are published or not. The documents may come from teaching and research institutions in France or abroad, or from public or private research centers.
L'archive ouverte pluridisciplinaire HAL, est destinée au dépôt et à la diffusion de documents scientifiques de niveau recherche, publiés ou non, émanant des établissements d'enseignement et de recherche français ou étrangers, des laboratoires publics ou privés. 
Two new long-legged flies in the Santonian amber of France (Diptera: Dolichopodidae)

André $\mathrm{Nel}^{\mathrm{a}}$, Romain Garrouste ${ }^{\mathrm{a}}$ and Christophe Daugeron ${ }^{\mathrm{b}}$

${ }^{a}$ Institut de Systématique, Évolution, Biodiversité, ISYEB - UMR 7205 - CNRS, MNHN, UPMC, EPHE, Muséum national d'Histoire naturelle, Sorbonne Universités, 57 rue Cuvier, CP 50, Entomologie, F-75005, Paris, France (anel@mnhn.fr, garroust@mnhn.fr)

${ }^{b}$ Muséum national d'Histoire naturelle, Centre National de la Recherche Scientifique, Mécanismes adaptatifs et évolution, UMR 7179 MNHN-CNRS MECADEV, CP 50, 45 rue Buffon, F-75005 Paris, France. (daugeron@mnhn.fr)

\begin{abstract}
Avenaphora gallica sp. nov., second representative of this dolichopodid genus, and Cretomicrophorus piolencensis sp. nov., third representative of this genus, are described from a new Early Santonian amber outcrop in Southern France. The relationships of Avenaphora in the Empidoidea are discussed. As for the modern Parathalassiinae, Avenaphora gallica and Cretomicrophorus piolencensis were found in a marine littoral swamp palaeoenvironment.
\end{abstract}

Keywords: Diptera; Empidoidea; Cretaceous amber; sp. nov.; palaeoecology

\title{
1. Introduction
}

The family Dolichopodidae is one of the five major lineages within the superfamily Empidoidea. The traditional concept of the family is referred to as Dolichopodidae sensu stricto. This concept was expanded to Dolichopodidae sensu lato to include the two small 
subfamilies Microphorinae and Parathalassiinae (Sinclair and Cumming, 2006). The dolichopodid characteristics comprise the Rs vein originating at or near the level of crossvein $\mathrm{h}$, crossvein $\mathrm{r}-\mathrm{m}$ situated in the basal fourth of the wing, and the male terminalia rotated forward beneath the preceding segments of the abdomen. The Dolichopodidae sensu lato are not rare in the Cretaceous ambers, the most frequently encountered being Microphorinae. This group comprises the modern genera Microphor Macquart, 1827 and Schistostoma Becker, 1902 and the extinct genera Avenaphora Grimaldi and Cumming, 1999 and Microphorites Hennig, 1971 (Perrichot and Engel, 2014). Among these taxa, Avenaphora remains quite enigmatic. Grimaldi and Cumming (1999) suggested that Avenaphora could have 'closer affinities to the Dolichopodidae and/or Parathalassiini', rather than to the Microphorinae. Cumming and Brooks (2002) proposed a sister-group relationship to the higher Dolichopodidae for this genus, while Ulrich (2004) considered it could be 'an early dolichopodine'. This genus is currently known by a unique male specimen in Early Cretaceous Lebanese amber (Grimaldi and Cumming, 1999). Here we describe the second fossil attributable to this genus together with the third representative of the Cretaceous genus Cretomicrophorus Negrobov, 1978, both from the Late Cretaceous amber of Piolenc (South of France), a new insectiferous amber rediscovered in the beginning of the years 2000 (Gomez et al., 2003). Very few insects were recovered in this amber, mainly Diptera (Choufani et al., 2013).

\section{Material and method}

The specimens are preserved in pieces of relatively clear, yellow amber. The amber pieces were cut, shaped, and polished. Then they were prepared between two coverslips with a Canada balsam medium as described in Azar et al. (2003), before being examined and photographed. Fossil was examined and measured under incident light with Olympus SZX9 
and Nikon SMZ1500 binocular microscopes, equipped with a Nikon D800 camera. We follow the terminology of Grimaldi and Cumming (1999) and the empidoid classification of Sinclair and Cumming (2006).

\section{Systematic palaeontology}

Family: Dolichopodidae Latreille, 1809

Subfamily: Parathalassinae Chvála, 1981:

Genus Avenaphora Grimaldi and Cumming, 1999

Type species. Avenaphora hispida Grimaldi and Cumming, 1999. Other species: Avenaphora gallica sp. n.

\section{Avenaphora gallica sp. n.}

(Fig. 1)

Derivation of name. Named after Gallica, the ancient Roman name for France

Material. Holotype MNHN.F.A53892, stored in the Laboratoire de Paléontologie, MNHN, Paris, France.

Type locality and horizon. Early Santonian, in amber, ancient sand quarry of Saint Louis, Piolenc, Vaucluse, France (Gomez et al., 2003).

Diagnosis. Body and wing very small (wing $0.7 \mathrm{~mm}$ long, body $0.7 \mathrm{~mm}$ long); veins $\mathrm{M} 1$ and M2 clearly reaching wing margin; anal lobe narrow.

Description. Body length ca. $0.7 \mathrm{~mm}$; thorax length ca. $0.3 \mathrm{~mm}$; wing length $0.7 \mathrm{~mm}$. Known only from female holotype.

Head relatively broad, slightly broader than thorax. Eye bare. Frons wide, margins of eyes diverging dramatically posteriad; frons with three pairs of frontal-orbital setae, anterior pair inclined and slightly cruciate, middle and posterior pairs reclinate; pair of small ocellar setae; 
pair of cruciate postocellars, pair of lateroclinate outer verticals. Antenna with scape bearing two setae; cuplike pedicel, distal margin with ring of fine setulae; flagellomere 1 dropshaped, ventral surface with longer setulae; arista with two articles (suture between aristomeres well visible), distal article whiplike, with numerous microtrichia slightly longer than width of aristal trunk; total length of arista slightly more than three times length of flagellomere 1. Proboscis not easily discerned, retracted into oral cavity.

Thorax: notum hardly arched; dorsocentrals and acrostichals differentiated; acrostichals in two median rows, about six setae per row; dorsocentrals slightly larger, five per row, posterior pair of dorsocentrals twice length of anterior three pairs. One supra-alar, one postpronotal, two pairs of scutellar setae. Scutellar setae longer than posteriormost dorsocentrals, almost upright; apical scutellars cruciate. Legs of moderate length, bristly. Forelegs: femur with two long ventral setae, basitarsomere with ventral comb of fine, short setae; tibial anteroapical comb apparently present. Midlegs: trochanter appears unusually long; tibia with three apical and one preapical seta. Hind legs: femur slightly stouter than others, basitarsus with pair of ventro-apical setae; tibial posteroapical comb present; no dorso-medial projection on tarsomeres 5 .

Wing relatively short, broad, length $2.7 \times$ greatest width, anal lobe of relatively small size, alula absent. Costa extended to apex of R4+5; costal seta present, costal vestiture with a single row of spine-like setae. Sc very difficult to discern; R1 short, no pterostigma; Rs origin opposite humeral crossvein, $\mathrm{R} 2+3$ and $\mathrm{R} 4+5$ nearly straight and simple; rm crossvein very short, cell dm absent; M1+2 forked, both veins clearly reaching wing margin; CuA1 well developed; cells bm and cup slender, of subequal length; bm-cu vein complete, apex of $\mathrm{CuA} 2$ not looped into cell bm; vein A1 extended to midway between cell cup and wing margin.

Abdomen relatively short and stout. Female genitalia hardly visible, except for ca. 3-4 acanthophorite spines. 
Discussion. This fossil corresponds to the diagnosis of the genus Avenaphora: eyes bare, broadly dichoptic (in male after Grimaldi and Cumming, 1999, but also present in this female); antenna with two-articled arista; frons with three pairs of frontal-orbital setae, anterior pair inclined. Wing with costal vein ending at R4+5; R1 short; cell dm absent (dm-cu vein absent); M1+2 forked; cell bm slender, bm-cu vein complete; cell cup narrow, subequal to length of cell bm, truncate apically; anal vein (A1) present, extended midway to wing margin; anal lobe of moderate size. Only the structures of the male genitalia are unknown because it is a female specimen. Thus we consider that our fossil belongs to this genus. Our fossil differs in very few points from the type species Avenaphora hispida, i.e., body and wing sizes much smaller than in A. hispida (wing $0.7 \mathrm{~mm}$ instead of $0.96 \mathrm{~mm}$, body $0.7 \mathrm{~mm}$ long instead of $1.16 \mathrm{~mm}$ ); veins M1 and M2 are clearly reaching the wing margin in A. gallica; anal lobe narrower than in A. hispida. The body chaetotaxy is the same in both species.

In the key to the families of Sinclair and Cumming (2006), the vein R4+5 unbranched would support an attribution to the Dolichopodidae sensu lato, Hybotidae, or Atelestidae. The base of Rs near the humeral vein and the basal cells shortened so that the crossvein r-m occurs in the basal fourth of wing are character states supporting an attribution to the Dolichopodidae sensu lato (Microphorinae + Dolichopodidae) (Sinclair and Cumming, 2006: 81), rather than to the Hybotidae and the Atelestidae. The apex of antenna usually with lengthened, bristlelike style would also exclude an attribution to the Atelestidae.

Nevertheless the Microphorinae have a discal cell, M1 and M2 arising independently on it, and costa running around the wing (Chvála, 1983; Sinclair and Cumming, 2006), unlike A. gallica.

The Dolichopodidae sensu stricto have no M2 and the costa ending on M1, unlike A. gallica (Chvála, 1983; Sinclair and Cumming, 2006). Among the Parathalassinae (see list of modern genera in Sinclair and Cumming (2006), only some species (viz. E. platypalpus 
Shamshev and Grootaert, 2005) of the genus Eothalassius Shamshev and Grootaert, 2005 have no discal cell and a vein M2 (Negrobov, 1978; Ulrich, 1991, 2004; Cumming and Brooks, 2002; Shamshev and Grootaert, 2002; Brooks and Cumming, 2011). E. platypalpus has a venation very close to that of Avenaphora. But Eothalassius differs from Avenaphora in the one-segmented style (Shamshev and Grootaert, 2005). The recent genus Neothalassius Brooks and Cumming, 2016 has also no discal cell but differs from Avenaphora in the absence of the vein M2 (Brooks and Cumming, 2016).

Avenaphora remains a Dolichopodidae (sensu lato) of uncertain affinities, but it shows more similarities with the Parathalassinae than with the Microphorinae or the Dolichopodidae s.str.

Genus Cretomicrophorus Negrobov, 1978

Type species. Cretomicrophorus rohdendorfi Negrobov, 1978. Other species: Cretomicrophorus novemundus Grimaldi and Cumming, 1999, Cretomicrophorus piolencensis sp. nov.

Cretomicrophorus piolencensis sp. nov.

(Figs. 2-3)

Derivation of name. Named after Piolenc, type locality.

Material. Holotype MNHN.F.A53893, stored in the Laboratoire de Paléontologie, MNHN, Paris, France.

Locality and horizon. Early Santonian, in amber, ancient sand quarry of Saint Louis, Piolenc, Vaucluse, France (Gomez et al., 2003). 
Diagnosis. Hind tibiae bearing three anterodorsal setae and five stout apicals; middle tibiae bearing six stout apicals; six pairs of acrostichals; scutellum with only long, apical pair of setae; C extending to R4+5; no pterostigma.

Description. Body ca. $1.8 \mathrm{~mm}$ long. Head strongly deformed in its anterior part, $0.3 \mathrm{~mm}$ long, $0.4 \mathrm{~mm}$ high; ocellar tubercle not displaced forward; frons and face not visible between eyes due to the deformation of this part of head; two stout ocellar setae, several setae around ocellar tubercle; two stout inner verticals , two stout postverticals; eyes bare, not contacting; setae along posterior eye margin (postocular bristles) arranged in one row from above to below; genae not developed; antennae located on apical third of head; scape very short, pedicel lacking apical process, but with apical circlet of setae, first flagellomere bulbiform, apically pointed; its length exceeding its thickness; arista apical one-segmented; proboscis hardly visible, short; palpus small. Thorax short, $0.6 \mathrm{~mm}$ long with the following distinct setae: 1 propleural, 1 postpronotal, 2 notopleurals, 1 supra-alar, 6 pairs of acrostichals, 8 pairs of dorsocentrals, 2 stout scutellars; mesopleura bare. Legs comparatively short, with well differentiated stout setae; femora not thickened; tarsi not broadened. Fore tibia bearing several stout antero- and posterodorsal setae, but lacking stout apicals; mid coxa with two stout setae; mid trochanter with several long apical setae; mid tibia with 2 antero- and posterodorsals, 6 stout apicals; hind coxa with 1 stout seta; hind tibia with 3 anterodorsals and 5 stout apicals; no dorso-medial projection on tarsomeres 5. Wings hyaline, $1.26 \mathrm{~mm}$ long; venation nearly identical to that of the modern Microphorella praecox (Loew); no pterostigma; C extending to R4+5, Sc entering C; costal cell large; R2+3 simple; simple R4+5 terminating at wing tip; vein bm-cu not complete; anal lobe weakly developed. Abdomen cylindrical, short, $0.9 \mathrm{~mm}$ long, bearing one stout dorsal seta on the first five segments; segment 7 clearly seen externally, not reduced; segment 8 located at apex of abdomen; hypopygium displaced onto right side, its apex extending onto abdominal tergite 5. 
Discussion. Following Sinclair and Cumming (2006), Cretomicrophorus piolencensis sp. nov. can be attributed to the Dolichopodidae sensu lato for the following diagnostic characters: Rs originating at or near level of crossvein h; basal cells shortened (less than half length of cell $\mathrm{dm}$ ) so that crossvein $\mathrm{r}-\mathrm{m}$ occurs in the basal fourth of wing; vein $\mathrm{R} 4+5$ unbranched; male terminalia rotated (lateroflexed) forward beneath the preceding segments with the pregenital segments partially twisted or rotated. It shares with the Parathalassiinae the following diagnostic characters: antennae inserted high on head; dichoptic males, narrow wing (anal lobe not developed); crossvein bm-cu incomplete; single segmented arista. The Microphorinae are excluded because they have holoptic male, broad wings (i.e., anal lobe developed), two-segmented arista, and costa circumambient. The modern Parathalassiinae includes the following genera: Amphithalassius Ulrich, 19991, Chimerothalassius Shamshev and Grootaert, 2003, Eothalassius Shamshev and Grootaert, 2005, Microphorella Becker, 1909, Parathalassius Mik, 1891, Plesiothalassius Ulrich, 1991, Thalassophorus Saigusa, 1986, and Neothalassius Brooks and Cumming, 2010. Ulrich (2004) listed the Cretaceous genus Archichrysotus Negrobov, 1978 in this group and maybe also Avenaphora (see above), while Sinclair and Cumming (2006) listed the genera Cretomicrophorus Negrobov, 1978, Archichrysotus, and Retinitus Negrobov, 1978 in this group on the basis of the single articled stylus.

C. piolencensis differs from Microphorella, Thalassophorus, and Parathalassius in the bare eye, and the presence of several strong setae on the legs (Smith, 1972; Chvála, 1983; Saigusa, 1986). Chimerothalassius, Eothalassius, Plesiothalassius, Amphithalassius, and Neothalassius have also no strong and long setae on legs (Ulrich, 1991, Shamshev and Grootaert, 2002, 2005; Brooks and Cumming, 2016). Chimerothalassius has also distinctly shorter setae on mesoscutum. Eothalassius has distinctly longer arista than in C. piolencensis. 
Archichrysotus and Retinitus differ from C. piolencensis in the presence of very few setae on tibiae (Negrobov, 1978).

C. piolencensis fits quite well with the diagnosis of Cretomicrophorus (Negrobov, 1978). Differences with C. rohdendorfi (Taymyr amber, Siberia, Santonian) are very few: hind tibiae bearing three anterodorsal setae (instead of two) and five stout apicals (instead of three); mid tibia bearing six stout apicals instead of four; scutellum with only long, apical pair of setae, no pair of smaller, anterior ones; $\mathrm{C}$ extending to $\mathrm{R} 4+5$ instead of $\mathrm{M} 1+2$. $C$. piolencensis differs from C. novemundus (New Jersey amber, Turonian) in the presence of six pairs of acrostichals (vs. four); no pterostigma.

\section{Palaeoecology}

After Ulrich (2004), the Microphorinae (recent and fossil) are supposed to be terrestrial, while the modern Parathalassiinae and the most 'basal' representatives of the 'higher' Dolichopodidae are living in the marine littoral. Interestingly the outcrop of lignites and sands of Piolenc is considered as resulting from marine littoral swamps and sediments (Gomez et al., 2003). Thus the presence of two Parathalassiinae would fit well with Ulrich's hypothesis.

Acknowledgements. We sincerely thank xxxxx referees .....

\section{References}

Azar, D., Perrichot, V., Néraudeau, D., Nel, A., 2003. New psychodids from the Cretaceous ambers of Lebanon and France, with a discussion of Eophlebotomus connectens Cockerell, 1920 (Diptera, Psychodidae). Annals of the Entomological Society of America 96, 117-126. 
Brooks, S.E., Cumming, J.M., 2011. The New World genera of Parathalassiinae (Diptera: Empidoidea: Dolichopodidae s.1.), with new species of Thalassophorus and Eothalassius. The Canadian Entomologist 143, 423-446.

Brooks, S.E., Cumming, J.M., 2016. Neothalassius, a new genus of Parathalassiinae (Diptera: Dolichopodidae s.lat.) from the Pacific coast of South America. Zootaxa 4066, 311-322.

Choufani, J., Perrichot, V., Girard, V., Garrouste, R., Azar, D., Nel, A., 2013. Two new biting midges of the modern type from Santonian amber of France (Diptera: Ceratopogonidae). pp. 75-95. In: Azar, D., Engel, M.S., Jarzembowski, E., Krogmann, L., Nel, A., Santiago-Blay, J. (eds). Insect Evolution in an Amberiferous and Stone Alphabet. Proceedings of the 6th International Congress on Fossil Insects, Arthropods and Amber.

Chvála, M., 1983. The Empidoidea (Diptera) of Fennoscandia and Denmark. 2. General part. The families Hybotidae, Atelestidae and Microphoridae. Fauna Entomologica Scandinavica $12,1-279$.

Cumming, J.M., Brooks, S.E., 2002. Electrophorella, a new genus of parathalassiine flies from Baltic amber, with a cladistic analysis of the Microphorinae + Dolichopodidae lineage (Diptera: Empidoidea). Studia Dipterologica 9, 41-54.

Gomez, B., Barale, G., Saad, D., 2003. Santonian angiosperm-dominated leaf-assemblage from Piolenc (Vaucluse, Sud-Est de la France). Comptes-Rendus Palevol 2, 197-204.

Grimaldi, D.A., Cumming, J., 1999. Brachyceran Diptera in Cretaceous ambers and Mesozoic diversification of the Eremoneura. Bulletin of the American Museum of Natural History 239, $1-124$.

Melander, A.L., 1927. Diptera fam. Empididae. Genera Insectorum 185, 1-434.

Negrobov, O.P., 1978. Flies of the superfamily Empidoidea (Diptera) from Cretaceous retinite in Northern Siberia. Paleontological Journal 12, 221-228. 
Perrichot, V., Engel, M.S., 2014. Youngest occurrence of the genus Microphorites (Diptera: Dolichopodidae): A new species in Late Cretaceous Vendean amber. Paleontological Contributions 10G: 30-33.

Saigusa, T., 1986. New genera of Empididae (Diptera) from Eastern Asia. Sieblodia 5, $97-$ 118.

Shamshev, I.V., Grootaert, P., 2002. A new genus of Microphorinae (Diptera: Empidoidea) from New Zealand. Belgian Journal of Entomology 4, 129-144.

Shamshev, I.V., Grootaert, P., 2005. Eothalassius, a new genus of parathalassiine flies (Diptera: Empidoidea: Dolichopodidae) from Southeast Asia and Pupua New Guinea. European Journal of Entomology 102, 107-118.

Sinclair, B.J., 1997. Icasma Collin and an allied new genus Glyphidopeza, from New Zealand (Diptera: Empidoidea; Ceratomerinae). Records of the Australian Museum, 49 (2): 195-211.

Sinclair, B.J. and Cumming, J.M. 2006. The morphology, higher-level phylogeny and classification of the Empidoidea (Diptera). Zootaxa 1180, 1-172.

Smith, K.G.V., 1972. A remarkable new Parathalassius (Diptera: Empididae) from South Africa, with a key to world species. Annals of the Natal Museum 21, 455-458.

Ulrich, H., 1991. Two new genera of parathalassiine-like flies from South Africa (Diptera: Empidoidea). Bonner Zoologische Beiträge 42, 187-216.

Ulrich, H., 2004. Phylogenetic considerations about an early colonization of the sea coasts by Dolichopodidae (Diptera). Studia Dipterologica 11, 233-243.

Fig. 1. Avenaphora gallica sp. n., holotype MNHN.F.A53892. A. Habitus, ventral view; B. Wing. Scale bar $=0.1 \mathrm{~mm}(\mathrm{~A}, \mathrm{~B})$.

Fig. 2. Cretomicrophorus piolencensis sp. nov., holotype MNHN.F.A53893. Habitus. Scale bar $=0.5 \mathrm{~mm}$. 
Fig. 3. Cretomicrophorus piolencensis sp. nov., holotype MNHN.F.A53893. A. Head; B. wing. Scale bar $=0.1 \mathrm{~mm}(\mathrm{~A}), 0.5 \mathrm{~mm}(\mathrm{~B})$. 
Click here to download high resolution image
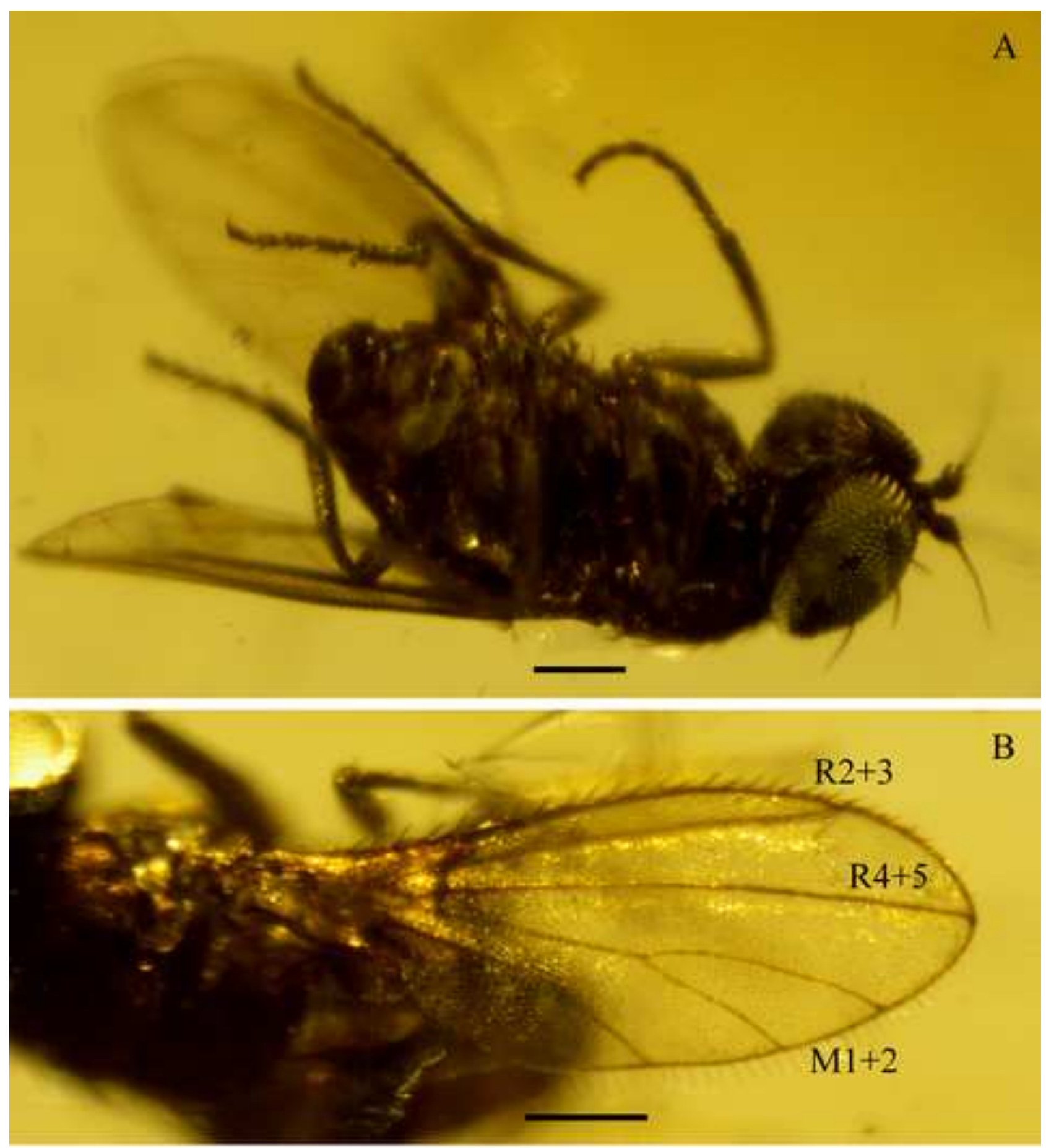
Click here to download high resolution image

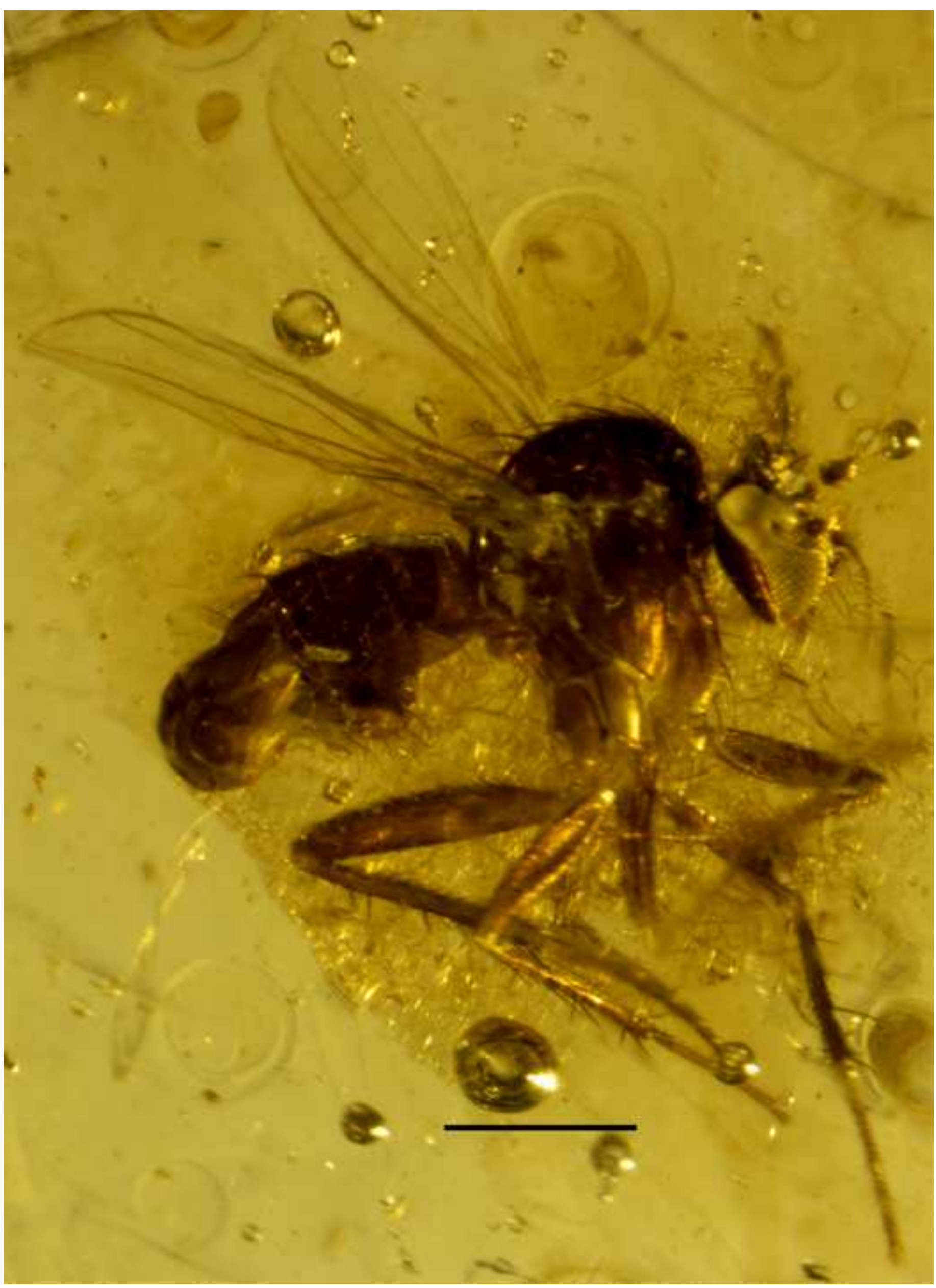


Figure 3
Click here to download high resolution image
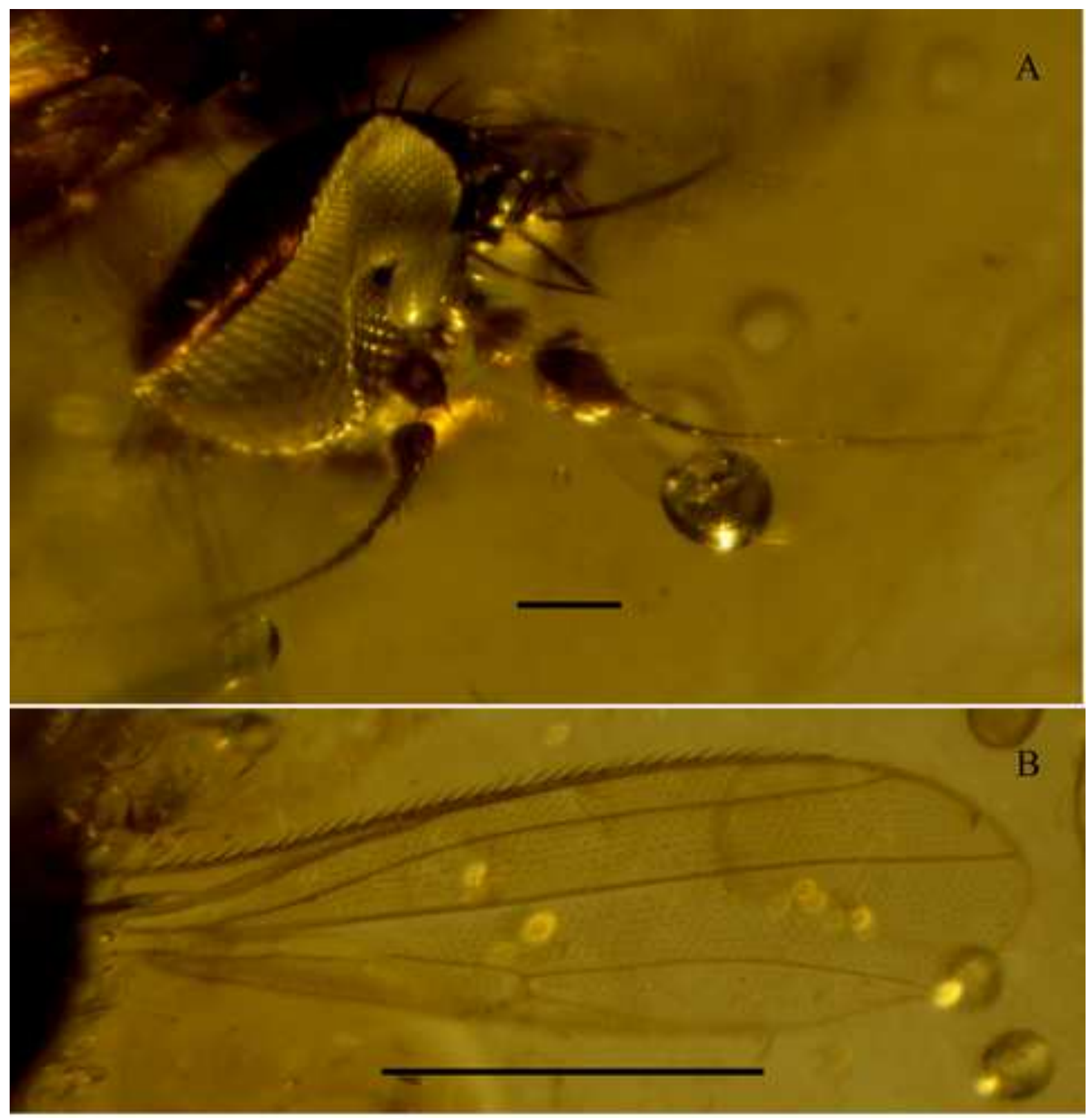